\title{
Lesion regeneration rates in reef-building corals Montastraea spp. as indicators of colony condition
}

\author{
Elizabeth M. Fisher ${ }^{1, *}$, John E. Fauth ${ }^{2}$, Pamela Hallock ${ }^{1}$, Cheryl M. Woodley $^{3}$ \\ ${ }^{1}$ College of Marine Science, University of South Florida, 140 Seventh Avenue South, St. Petersburg, Florida 33701, USA \\ ${ }^{2}$ Department of Biology, University of Central Florida, 4000 Central Florida Boulevard, Orlando, Florida 32816, USA \\ ${ }^{3}$ US National Oceanic and Atmospheric Administration, National Ocean Service, Center for Coastal Environmental Health \\ and Biomolecular Research, Hollings Marine Laboratory, 331 Ft. Johnson Road, Charleston, South Carolina 29412, USA
}

\begin{abstract}
Regeneration rates of coral lesions reflect the ability of colonies to repair damage and therefore can be useful indicators of coral health and environmental conditions. We quantified regeneration rates of boulder corals Montastraea spp. at four, $6 \mathrm{~m}$ deep patch reefs within Biscayne National Park (BNP) and the upper Florida Keys National Marine Sanctuary (FKNMS), and along a 3 to $18 \mathrm{~m}$ depth transect in FKNMS. Coral lesions (approx. $2 \mathrm{~cm}^{2}$ ) created during sampling for cellular-diagnostic analysis were monitored quarterly in 2001 and 2002, and in February 2003. Regeneration was a dynamic process, continuing longer than previously reported ( $>300 \mathrm{~d}$ after lesion formation). Geographic location was the strongest factor affecting regeneration rate at our study sites. Lesion regeneration differed significantly among $6 \mathrm{~m}$ deep sites; sites offshore from John Pennekamp Coral Reef State Park (Algae Reef and White Banks) consistently had the highest regeneration rates, with colonies exhibiting exponential declines in lesion size and a high percentage of completely healed lesions. Along the depth gradient, corals at the $3 \mathrm{~m}$ site regenerated significantly faster than corals at 6, 9, and $18 \mathrm{~m}$. These results suggest that corals sampled at FKNMS 6, 9 and $18 \mathrm{~m}$ sites and BNP were in poor physiological condition or were exposed to suboptimal environmental conditions, as evidenced by highly variable and overall low regeneration rates, a low percentage of healed lesions, and a high occurrence of breakage or Type II lesions (lesions that increased in size by merging with areas of denuded tissue on the colony).
\end{abstract}

KEY WORDS: Regeneration · Indicators · Lesion · Montastraea spp. · Coral · Partial mortality · Damage

\section{INTRODUCTION}

Most corals are colonial organisms; a colony can experience partial mortality in which a portion remains alive while another portion dies. When a disturbance produces a lesion (partial mortality), the exposed coral skeleton becomes vulnerable to invasion by sessile organisms such as algae, resulting in the lesion increasing in size. Alternatively, healing can occur if tissue regeneration processes are not impeded (Kawaguti 1937). Lesions that fail to heal completely within about 2 mo are likely to become permanent patches of mortality (Meesters et al. 1994).
Percent mortality of coral colonies is a useful gauge of reef condition (Ginsburg et al. 2001) because it can point to a recent or chronic disturbance (Lang 2003) and can influence colony growth and reproduction (Meesters et al. 1994, Van Veghel \& Bak 1994, Lirman 2000a). Williams (1994) proposed using coral lesions as indicators of environmental stress because they are a generalized response to a range of disturbances, are independent of reef type, and can be monitored by resource managers easily and inexpensively. Williams (1994) noted that the frequency of coral lesions varies among sites, with polluted sites having more lesions than relatively unpolluted sites. Quantifying colony 
damage and recovery rates also are essential for predicting demographic changes in coral populations (Bak \& Meesters 1999).

In corals, lesion regeneration begins with growth of an undifferentiated tissue layer created by the coenenchyme and polyps surrounding the lesion (Bak et al. 1977). After about $2 \mathrm{wk}$, polyps begin to develop in the new tissue (Meesters et al. 1994) and secrete thecal walls and a basal plate. These give rise to numerous radially arranged calcareous partitions (septa), which project inward and support the polyp mesenteries. Pigmentation and zooxanthellae return at the end of the regeneration process (Bak et al. 1977, Kramarsky-Winter \& Loya 2000). Coral regeneration rates can vary with species (Kawaguti 1937, Bak et al. 1977, Nagelkerken \& Bak 1998) and are influenced by lesion characteristics including the type of injury and its initial size, perimeter and shape (Meesters et al. 1994, 1997b, Oren et al. 1997, Lirman 2000b, Hall 2001), and colony characteristics such as size (Kramarsky-Winter \& Loya 2000, Oren et al. 2001). Under normal conditions, lesion size decreases exponentially; deviations from this response suggest resource limitation (Meesters et al. 1997b), stress due to environmental conditions (Lester \& Bak 1985, Meesters \& Bak 1993, Meesters et al. 1993, Mascarelli \& BunkleyWilliams 1999, Croquer et al. 2002, Fine et al. 2002) or competition (Hall 2001).

The present study was part of a long-term project in the Florida Keys testing the use of an integrated molecular biomarker system in corals (Downs et al. 2000, 2005, Fauth et al. 2003). Here we compare the ability of star boulder corals (Montastraea species complex) within 2 marine protected areas, to regenerate biopsyinduced lesions. Lesion regeneration rates were assessed to characterize coral condition at these sites. Three specific questions were addressed: (1) Do regeneration rates differ among sites, seasons or years? (2) Do regeneration rates vary with depth? (3) Do regeneration rates vary with lesion parameters (e.g. initial lesion size, perimeter, shape) or colony characteristics (e.g. morphotype/species, size, \% mortality)? In future papers, we will relate coral regeneration rates to ecological and cellular indicators to further identify potential sources of stress at our study sites.

\section{MATERIALS AND METHODS}

Study sites. We assessed reef condition at community and colony scales at 1 patch reef (Alina's Reef) in Biscayne National Park (BNP), and 4 patch reefs and 2 fore reef sites in the upper Florida Keys National Marine Sanctuary (FKNMS), as part of an ongoing study of coral ecophysiology (e.g. Downs et al. 2000,
2005, Fauth et al. 2003). These 7 sites (Fig. 1) comprised both a latitudinal transect with 4 sites at $6 \mathrm{~m}$ depth and a depth transect (Key Largo, KL, 3 to $18 \mathrm{~m}$ ) and were chosen in consultation with resource managers to reflect gradients in environmental conditions. Algae Reef (AR) and White Banks (WB) were adjacent to the extensive John Pennekamp Coral Reef State Park, with intact coastal hammock, mangroves and seagrass beds. Key Largo 6 m (KL 6 m) was located offshore from the most urbanized coastline of Key Largo, from which natural vegetation has been removed, natural topography has been altered to maximize waterfront properties, and coastlines are lined with seawalls. This site lies along the route that recreational boaters and commercial dive operators take to reach popular Molasses Reef and other outer reefs in the Upper Keys reef tract. Molasses Reef is 'the most heavily visited reef in the Upper Keys for diving' (FKNMS website). Biscayne National Park (BNP) is offshore from urban

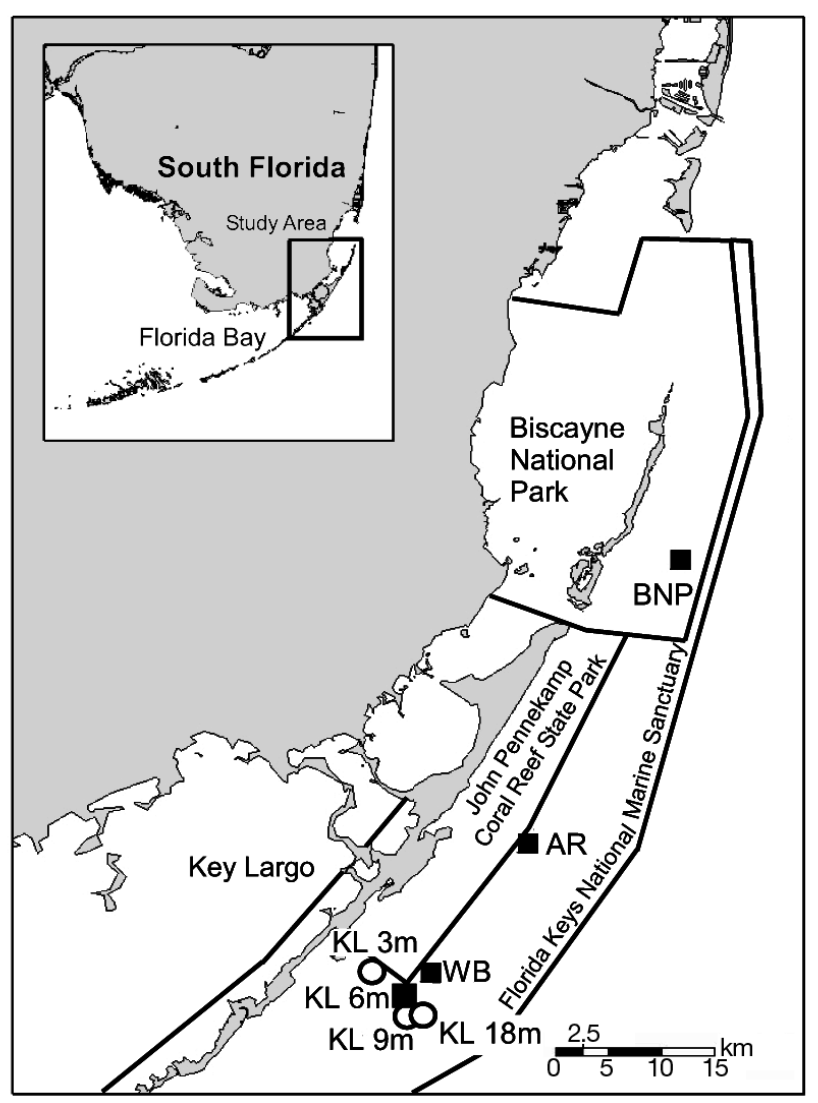

Fig. 1. Study sites. $\mathbf{0}$ : $6 \mathrm{~m}$ sites, comprising patch reefs Key Largo (KL) $6 \mathrm{~m}\left(25^{\circ} 01.09^{\prime} \mathrm{N}, 80^{\circ} 23.84^{\prime} \mathrm{W}\right)$, White Banks (WB) $\left(25^{\circ} 02.23^{\prime} \mathrm{N}, 80^{\circ} 22.50^{\prime} \mathrm{W}\right)$, Algae Reef (AR) $\left(25^{\circ} 08.80^{\prime} \mathrm{N}\right.$, $\left.80^{\circ} 17.60^{\prime} \mathrm{W}\right)$, and Alina's Reef in Biscayne National Park (BNP) $\left(25^{\circ} 23.19^{\prime} \mathrm{N}, 80^{\circ} 09.78^{\prime} \mathrm{W}\right)$; O: along depth gradient, comprising 2 patch reefs, KL $3 \mathrm{~m}\left(25^{\circ} 02.45^{\prime} \mathrm{N}, 80^{\circ} 25.44^{\prime} \mathrm{W}\right)$ and $\mathrm{KL} 6 \mathrm{~m}$, and 2 fore reefs, $\mathrm{KL} 9 \mathrm{~m}\left(25^{\circ} 00.15^{\prime} \mathrm{N}\right.$, $\left.80^{\circ} 23.63^{\prime} \mathrm{W}\right)$ and $\mathrm{KL} 18 \mathrm{~m}\left(25^{\circ} 00.21^{\prime} \mathrm{N}, 80^{\circ} 23.02^{\prime} \mathrm{W}\right)$ 
Miami, Florida, which is potentially influenced by the extensive agricultural area south and west of Miami that drains into Biscayne Bay. BNP also is located in proximity to a nuclear power plant and major landfill site.

Benthic community assessments. In March 2002, a dive was made at each $6 \mathrm{~m}$ site to assess the benthic organisms using the rapid assessment methods described by Lang (2003). At each site, a $10 \mathrm{~m}$ transect line was placed just above a haphazardly selected area of reef surface and live coral cover was determined by estimating the amount of living coral directly beneath the line. For each coral $>10 \mathrm{~cm}$ in diameter lying beneath the transect, we recorded species, maximum diameter and height, and percent recent and old mortality. 'Recently dead' was defined as any non-living parts of the coral in which the corallite structures were still intact or covered by a thin layer of algae or fine mud (Lang 2003). 'Long dead' was defined as any nonliving parts of the coral in which the corallite structures were either gone or covered by organisms that were not easily removed (Lang 2003). Because of differences in reef types, we could not use this method for comparisons along the depth gradient.

Lesion regeneration. Between June 2001 and February 2003, we collected tissue samples (creating a lesion) approximately quarter-yearly (February/ March, June, August, October/November) from the same 5 colonies at each site. Previous studies showed that quarterly sampling was adequate to detect changes in coral physiology as a result of seasonal and stressor variation (Downs et al. 2000, Fauth et al. 2003). We preferentially chose Montastraea faveolata for this study but sampled the morphotypes $M$. annularis and $M$. franksi when $M$. faveolata was not available. A single morphotype was not found at all study sites: We sampled $M$. faveolata at all sites except KL $18 \mathrm{~m}$, $M$. annularis at KL $6 \mathrm{~m}$ and $\mathrm{WB}$, and $M$. franksi at KL 9 and $18 \mathrm{~m}, \mathrm{WB}$, and AR. We estimated size (maximum diameter) and percent partial mortality of each colony at the start of the study. We measured diameter (live and dead areas) in planar view perpendicular to the axis of growth to the nearest $1 \mathrm{~cm}$ using a meter stick. Partial mortality was visually quantified by estimating the percentage of dead area from above in planar view as recommended by Lang (2003).

We removed coral tissue and skeleton using a leather punch, which created a circular lesion 1 to $2 \mathrm{~cm}^{2}$ in area and $3 \mathrm{~mm}$ deep. Experimental lesions were always completely surrounded by live tissue. We immediately filled the hole with clay (Roma plastilina, medium grey; Blick Art Materials) to fill the void produced by removing the underlying skeleton and limit intrusion of fouling and bioeroding organisms (Fig. 2). Use of clay filler was a decision made by park managers when permitting biopsy of these corals for molecular biomarker analysis. Clay provided corals with a flat surface over which to regenerate tissue but, as seen in our study, did not prevent fouling or bioerosion. However, the regeneration rates reported in this study may represent maximal rates due to a possible reduction in biofouling. We then photographed each lesion using a Nikonos V $35 \mathrm{~mm}$ camera with a close-up adapter and frame, calibrating measurements with a $4.5 \mathrm{~mm}$ long bar. We re-photographed each lesion during subsequent quarterly samplings to observe changes in size over time (Fig. 2). We scanned photographs to digital images and used image-analysis software (Image Pro $^{\mathrm{TM}}$ ) to calculate area (A) and perimeter $(\mathrm{P})$ of all lesions that remained completely surrounded by live tissue (Type I lesions: Meesters et al. 1997a).

If a lesion enlarged, thereby merging with an area of the colony that lacked tissue (Type II lesions: Meesters et al. 1997a), we conservatively assumed no change in lesion size for that sampling date and removed it from further analyses because subsequent changes in area were unconstrained. When lesions merged with other
A

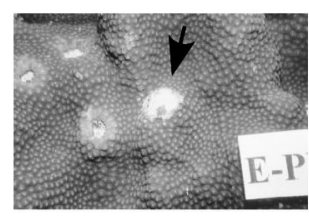

B

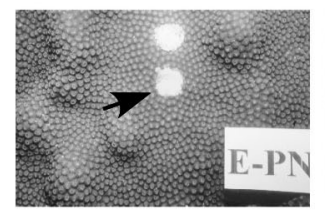

October 2001
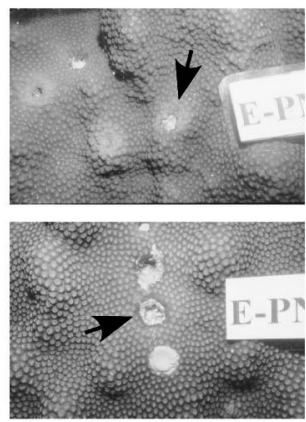

March 2002

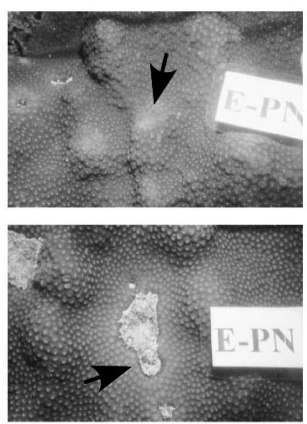

June 2002

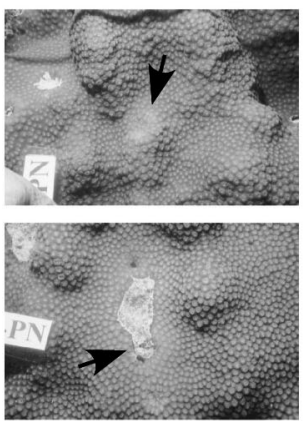

August 2002
HEALED

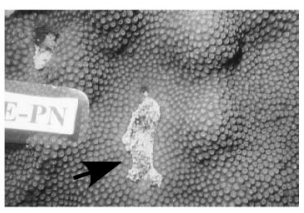

November 2002

Fig. 2. Montastraea spp. Examples of lesions at $6 \mathrm{~m}$ sites between October 2001 and November 2002 showing 2 extremes. (A) Algae Reef (lesion completely healed by June 2002); (B) Alina's Reef in BNP (lesion joined with other sampling lesions in June 2002 and became covered with turf algae). Black arrows point to relevant lesions 
created lesions (Fig. 2B), we calculated their area as $A_{L}=A_{T} / n_{\text {; }}$ where $A_{L}$ is the area of the lesion used for further analyses, $A_{T}$ is the total area of all lesions joined together, and $\mathrm{n}$ is the total number of lesions joined together. This calculation provided a conservative estimate of lesion area increase. In the few cases where initial lesion size was unavailable due to camera malfunctions, we substituted the average initial lesion size for that sampling period. When photographs of final lesion size were unavailable, we used in situ measurements to calculate lesion area and perimeter using the equation for an ellipse, $A_{L}=\pi a b$, and $P_{L}=2 \pi \cdot \operatorname{sqrt}\left[\left(a^{2}+\right.\right.$ $\left.b^{2}\right) / 2$ ], where $A_{L}$ is the area of the lesion, $P_{L}$ is the perimeter of the lesion, and $a$ and $b$ are one-half of lesion length and width, respectively. Larger lesions resulted from breakage of the coral skeleton, which was often highly bioeroded. Because of the effect of initial lesion size on regeneration, we removed lesions $>3.4 \mathrm{~cm}^{2}$ from further analyses.

Data analysis. Benthic community assessments: We used 1-way ANOVA followed by the Tukey-Kramer Honestly Significant Difference (HSD) test to determine if sites differed significantly in live coral cover and coral colony density. Data on coral diameter and height, and recent and old mortality did not meet the normality assumptions of ANOVA. For these data, we used Kruskal-Wallis followed by Wilcoxon rank-sum tests to test for differences among sites.

Lesion regeneration: Data were analyzed in 2 groups: (1) by sites at $6 \mathrm{~m}$ depth along the NE-SW traverse (BNP, AR, WB and KL $6 \mathrm{~m}$ ), and (2) by sites along the depth gradient (KL 3, 6, 9 and $18 \mathrm{~m}$ ). The KL $6 \mathrm{~m}$ site was common to both groups (Fig. 1). We examined lesion changes in 3 different ways to answer specific questions:

- Did lesion size decrease exponentially with time $\left(\mathrm{cm}^{2} \mathrm{~d}^{-1}\right)$ and did this differ among sites and seasons? Can deviations from this model be used as an indicator of stress? We used least-squares regression to fit an exponential model of regeneration with an asymptote as recommended by Meesters et al. (1994, 1997b):

$$
y=y_{0}+a \mathrm{e}^{-b \cdot t i m e}
$$

where $y_{0}$ is the asymptote, $a$ is the amount of tissue regenerated, and $b$ is the slope of the curve. We only applied the exponential model to lesions with a minimum of 1 yr of observations.

- Did regeneration rates differ among sites and seasons? We calculated rates for 2 different periods: shortterm (45 to $154 \mathrm{~d}$ ) and quasi-annual (319 to $376 \mathrm{~d}$ ). The shortest period monitored reflects a time frame similar to that in previous regeneration studies (e.g. Meesters et al. 1994, 1997b, Van Veghel \& Bak 1994). We calculated the quasi-annual rates to determine how lesion size changed over multiple seasons. For each lesion, we calculated the amount of tissue regenerated or lost $(\Delta \mathrm{T})$ as $\Delta \mathrm{T}=\%$ change in lesion size $\cdot$ initial lesion size/time. We standardized regeneration to initial lesion perimeter $(\mathrm{P})$ because this influenced regeneration rates. We used repeated-measures MANOVA to determine whether standardized regeneration rates $(\Delta \mathrm{T}: \mathrm{P})$ differed among sites, seasons and their interactions. We checked model assumptions (e.g. sphericity, homogeneity of variances, normality and independence) using residual plots. In cases where the sphericity assumption was not met, we applied a univariate (unadjusted epsilon) approach. To interpret effects detected by MANOVA, we used 1-way ANOVA followed by the Tukey-Kramer HSD test. We regressed residuals of the regeneration-rate model against lesion (A, P and shape [P:A]) and colony (species, size, \% mortality) parameters to determine if they affected regeneration rates. Any colony characteristics that explained significant variation in residuals were used as covariates in the MANOVA model. We also regressed quasi-annual regeneration rates against short-term rates to determine if monitoring for short time periods could be used to predict long-term trends.

- Were lesions among all sites capable of completely healing and did the number of Type II lesions differ among sites and seasons? We used G-tests of independence with William's correction (Sokal \& Rohlf 1995) to determine if the number of lesions that closed completely or progressed into Type II lesions differed among sites.

We performed non-linear regression using SigmaPlot 2000 (Systat Software) and all other statistical analyses using JMP Version 3.2 (SAS Institute), with $\alpha=0.05$ for all hypothesis tests.

\section{RESULTS}

\section{Community data}

Mean percent live coral cover and coral colony density were low at all $6 \mathrm{~m}$ sites; both were highest at AR and lowest at KL $6 \mathrm{~m}$ (coral cover: ANOVA $F_{3,13}=11.4$, $\mathrm{p}<0.0007$; coral colony density: ANOVA $F_{3,26}=3.7$, $\mathrm{df}=3, \mathrm{p}<0.03$; Table 1). Colonies at AR were significantly larger (maximum diameter) than colonies at WB and KL $6 \mathrm{~m}$; colonies at BNP were also significantly larger than colonies at KL $6 \mathrm{~m}\left(\chi^{2}=9.2\right.$, df $=3, \mathrm{p}<0.03$; Table 1).

\section{Regeneration model}

After removing lesions $>3.4 \mathrm{~cm}^{2}$ from further analyses, initial lesion area ranged from 0.75 to $3.02 \mathrm{~cm}^{2}$ 
Table 1. Montastraea spp. Comparison of benthic parameters at four $6 \mathrm{~m}$ patch reefs from $10 \mathrm{~m}$ transects using Atlantic Gulf and Rapid Reef Assessment protocol (Lang 2003). Data are means $( \pm$ SE); values not bearing same superscript are significantly different $(\mathrm{p}<0.05)$. Site abbreviations here and in Tables $2 \& 3$ as in Fig. 1 legend

\begin{tabular}{|c|c|c|c|c|c|c|c|}
\hline Site & $\mathrm{n}$ & $\begin{array}{l}\text { Colonies } \\
\left(\text { no. } \mathrm{m}^{-1}\right)\end{array}$ & $\begin{array}{l}\text { Live coral } \\
\text { cover }(\%)\end{array}$ & $\begin{array}{c}\text { Coral } \\
\text { height }(\mathrm{cm})\end{array}$ & $\begin{array}{c}\text { Coral } \\
\text { diam. }(\mathrm{cm})\end{array}$ & $\begin{array}{c}\text { Recent } \\
\text { mortality (\%) }\end{array}$ & $\begin{array}{c}\text { Old } \\
\text { mortality }(\%)\end{array}$ \\
\hline KL 6 m & 7 & $0.644^{\mathrm{A}}(0.07)$ & $7^{\mathrm{A}}$ & $11^{\mathrm{A}} \quad$ (3) & $21^{\mathrm{A}} \quad$ (5) & $3^{\mathrm{A}} \quad(2)$ & $11^{\mathrm{A}}$ \\
\hline WB & 8 & $0.71 \mathrm{AB}(0.07)$ & $9^{\mathrm{A}} \quad(1)$ & $13^{\mathrm{A}}$ (1) & $19 \mathrm{AB} \quad(2)$ & $2^{\mathrm{A}}$ & $8^{\mathrm{A}}$ \\
\hline AR & 8 & $0.94^{\text {В }}(0.10)$ & $16^{\text {B }}$ & $23^{\mathrm{A}}$ (4) & $40^{\mathrm{C}}$ & $2^{\mathrm{A}}$ & $12^{\mathrm{A}} \quad(3)$ \\
\hline BNP & 8 & $0.64^{\mathrm{A}}(0.05)$ & $8^{\mathrm{A}}$ & $25^{\mathrm{A}} \quad(6)$ & $37^{\mathrm{BC}}(8)$ & $4^{\mathrm{A}}$ & $19^{\mathrm{A}}$ \\
\hline
\end{tabular}

with a mean $( \pm$ SE hereafter $)$ of 1.75 $( \pm 0.04) \mathrm{cm}^{2}(\mathrm{n}=136)$ for the $6 \mathrm{~m}$ sites and from 0.68 to $3.32 \mathrm{~cm}^{2}$ with a mean of $1.80( \pm 0.05) \mathrm{cm}^{2}(\mathrm{n}=128)$ along the depth gradient.

Lesion size decreased exponentially over time at AR, WB and the KL $3 \mathrm{~m}$ site (Fig. 3) as indicated by large $r^{2}$ values and slopes (Table 2). With few exceptions, lesion size at BNP, and KL 6, 9 and $18 \mathrm{~m}$ either changed little or, in some cases, increased over time (Fig. 3). Lesions on corals at these sites deviated from the expected decay model and fit to either an exponential growth (increase in lesion size) model or a reduced model, as indicated by low $\mathrm{r}^{2}$ values and slopes (Table 2 ).

\section{Short-term regeneration rates (45 to $154 \mathrm{~d}$ )}

Short-term regeneration rates $(\Delta \mathrm{T}: \mathrm{P})$ ranged from -40 to $65 \times 10^{-4} \mathrm{~cm} \mathrm{~d}^{-1}$ with a mean of $13 \pm 1 \times 10^{-4} \mathrm{~cm} \mathrm{~d}^{-1}(\mathrm{n}=136)$ at $6 \mathrm{~m}$ sites and from -43 to $91 \times 10^{-4} \mathrm{~cm}$ $\mathrm{d}^{-1}$ with a mean of $13 \pm 2 \times 10^{-4} \mathrm{~cm} \mathrm{~d}^{-1}$ $(\mathrm{n}=127)$ along the depth gradient.

Mean short-term regeneration rates differed significantly among the $6 \mathrm{~m}$ sites (repeated-measures MANOVA: site effect $F_{3,10}=10.6, \mathrm{p}<0.002$; Fig. 4A), but not among species, seasons, or their interactions. Mean shortterm regeneration rates at AR were significantly higher than at the other $6 \mathrm{~m}$ sites, and short-term regeneration rates at WB were significantly higher than at KL $6 \mathrm{~m}$ and BNP (AR: $23 \pm 2 \times 10^{-4} \mathrm{~cm}$ $\mathrm{d}^{-1}$; WB: $15 \pm 2 \times 10^{-4} \mathrm{~cm} \mathrm{~d}^{-1}$; KL $6 \mathrm{~m}$ : $7 \pm 2 \times 10^{-4} \mathrm{~cm} \mathrm{~d}^{-1}$; BNP: $6 \pm 2 \times 10^{-4} \mathrm{~cm}$ $\mathrm{d}^{-1}$; Tukey's HSD test). Short-term re-
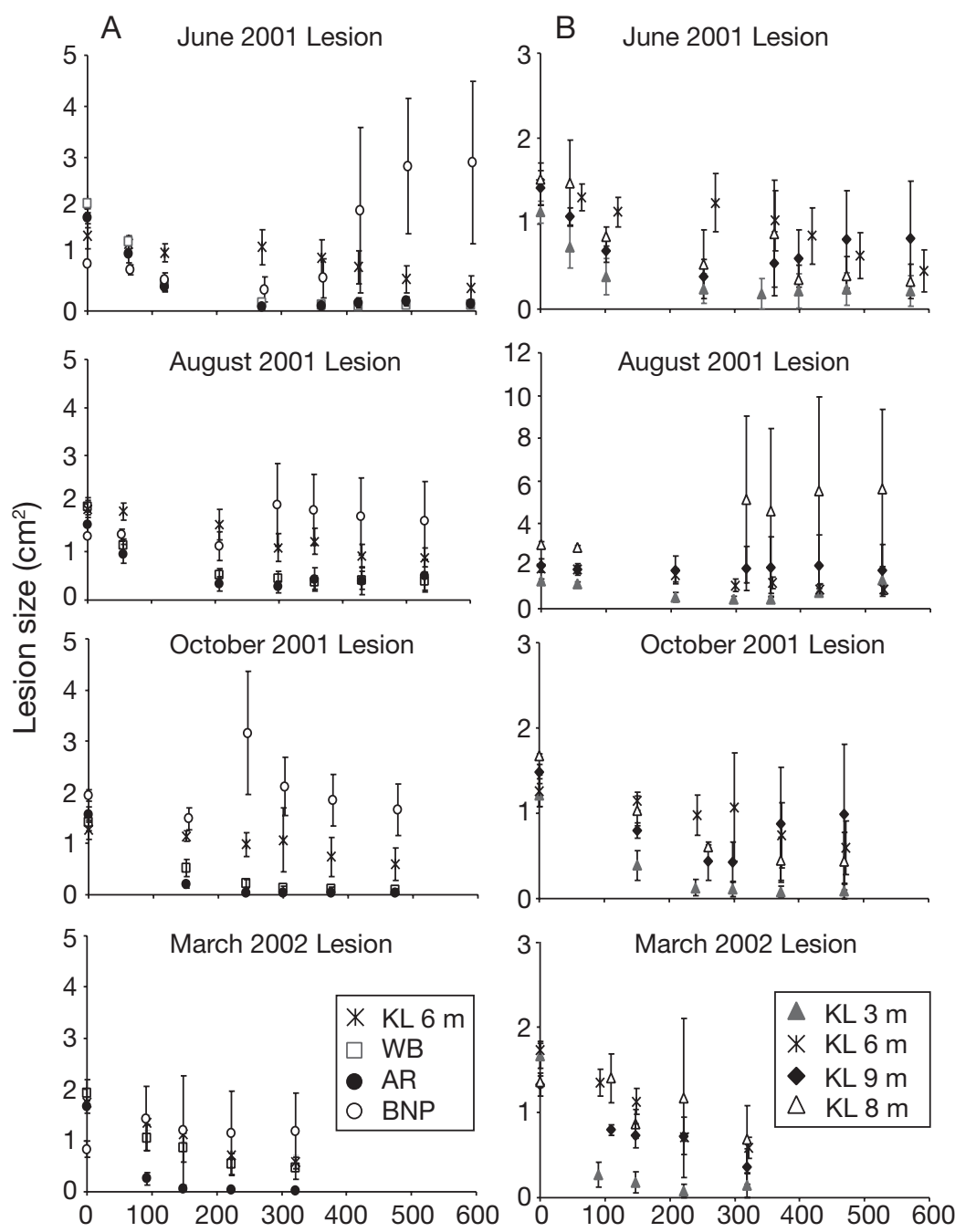

Time (d)

Fig. 3. Montastraea spp. Mean $( \pm \mathrm{SE})$ lesion size over time for each season between June 2001 and March 2002 (A) at $6 \mathrm{~m}$ sites and (B) along depth gradient. Merging of 2 sampling-induced lesions occurred at KL $9 \mathrm{~m}$ (in March 2002), at KL $18 \mathrm{~m}$ (in February 2003), and at BNP (in June 2002 and August 2002). An additional lesion joined with the previously merged lesions at BNP in October 2002. Lesions that progressed into Type II lesions or lesions for which data were removed for other reasons (breakage or initial size $>3.4 \mathrm{~cm}^{2}$ : see 'Materials and methods') were not included in means. Note expanded $y$-axis in graph showing lesion regeneration along depth gradient in August 2001. Site abbreviations here and in subsequent figures as in Fig. 1 legend 
Table 2. Montastraea spp. Mean $( \pm \mathrm{SE}) \mathrm{r}^{2}$ values of the 5 colonies for the regression decay model, $y=y_{0}+a \mathrm{e}^{-b \cdot \text { time }_{i}}$ zero $\mathrm{r}^{2}$ value was assumed for all lesions that did not fit this model. Last 2 columns show overall mean and slope $(b)\left(\mathrm{cm}^{2} \mathrm{~d}^{-1} \times 10^{-2}\right)$

\begin{tabular}{|c|c|c|c|c|c|c|}
\hline Site & $\begin{array}{c}\text { Jun } 2001- \\
\text { Jun } 2002\end{array}$ & $\begin{array}{c}\text { Aug 2001- } \\
\text { Aug } 2002\end{array}$ & $\begin{array}{l}\text { Oct 2001- } \\
\text { Nov } 2002\end{array}$ & $\begin{array}{c}\text { Mar 2002- } \\
\text { Feb } 2003\end{array}$ & $\begin{array}{c}\text { Overall } \\
\text { mean }\end{array}$ & Slope \\
\hline $\mathrm{KL} \quad 3 \mathrm{~m}$ & $0.95(0.03)$ & $0.52(0.22)$ & $0.94(0.05)$ & $0.98(0.01)$ & $0.85(0.07)$ & $2.1(0.7)$ \\
\hline $6 \mathrm{~m}$ & $0.55(0.18)$ & $0.61(0.15)$ & $0.33(0.18)$ & $0.88(0.07)$ & $0.59(0.09)$ & $0.3(0.1)$ \\
\hline $9 \mathrm{~m}$ & $0.58(0.19)$ & $0.39(0.24)$ & $0.55(0.23)$ & $0.72(0.24)$ & $0.55(0.11)$ & $0.1(0.1)$ \\
\hline $18 \mathrm{~m}$ & $0.56(0.22)$ & $0.37(0.22)$ & $0.72(0.24)$ & $0.71(0.24)$ & $0.59(0.11)$ & $0.4(0.2)$ \\
\hline WB & $0.97(0.01)$ & $0.98(0.01)$ & $0.98(0.02)$ & $0.90(0.07)$ & $0.96(0.02)$ & $1.2(0.2)$ \\
\hline AR & $0.96(0.01)$ & $0.80(0.20)$ & $1.00(0.00)$ & $1.00(0.00)$ & $0.93(0.05)$ & $1.7(0.3)$ \\
\hline BNP & $0.23(0.23)$ & $0.36(0.22)$ & $0.37(0.22)$ & $0.21(0.20)$ & $0.30(0.10)$ & $0.2(0.2)$ \\
\hline
\end{tabular}

generation rates also differed significantly along the depth gradient (repeated-measures MANOVA: site effect $F_{3,8}=4.4, \mathrm{p}<0.05$; Fig. 4B) but not with season or depth $\times$ season interactions. Short-term regeneration rates at KL $3 \mathrm{~m}$ were significantly faster than at

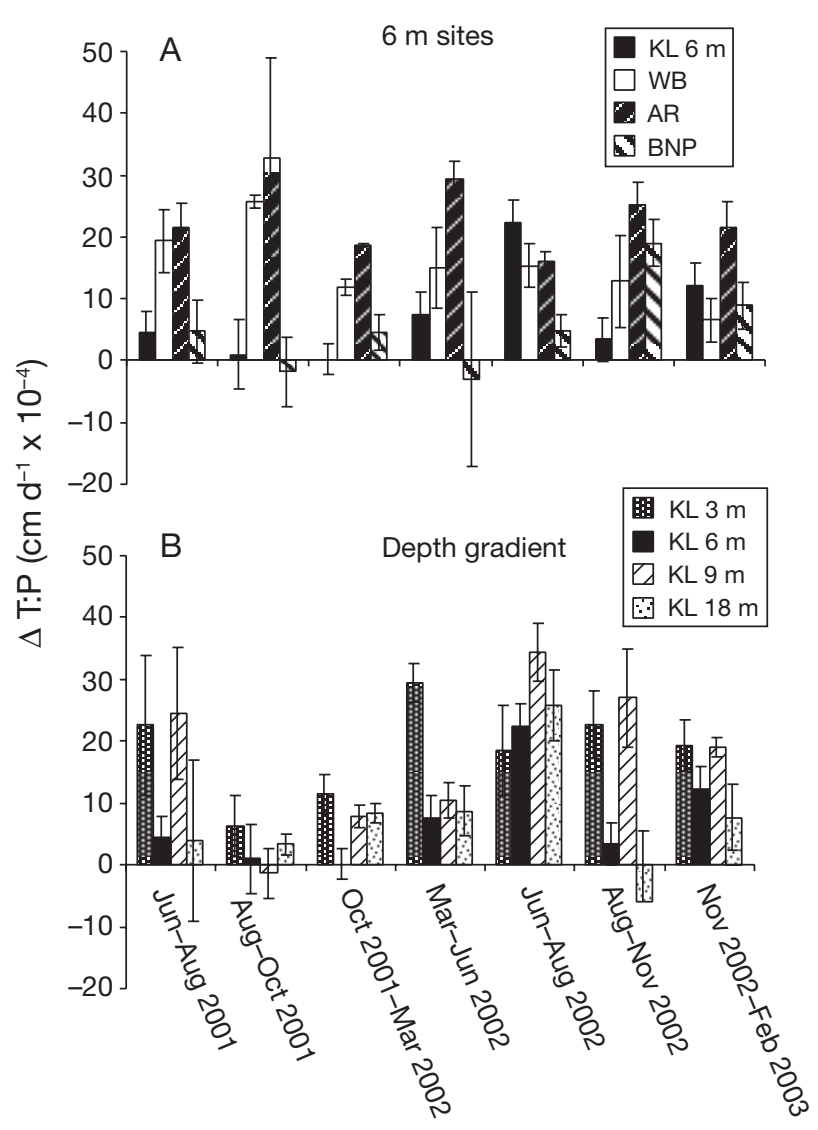

Fig. 4. Montastraea spp. Mean $( \pm \mathrm{SE})$ regeneration rates standardized to initial lesion perimeter $(\triangle \mathrm{T}: \mathrm{P})$ for each season, from one sampling event to next, (A) among $6 \mathrm{~m}$ sites, and (B) along depth gradient. Rates calculated between June and August 2001 (54 \pm 13 d), August and October 2001 (56 d), October 2001 and March $2002(153 \pm 2$ d), March and June $2002(91 \pm 1 \mathrm{~d})$, June and August $2002(48 \pm 13 \mathrm{~d})$, August and November 2002 (74 d) and November 2002 and February $2003(99 \pm 1 d)$
KL $6 \mathrm{~m}\left(19 \pm 3 \times 10^{-4} \mathrm{~cm} \mathrm{~d}^{-1}\right.$ vs. $7 \pm 2 \times 10^{-4} \mathrm{~cm} \mathrm{~d}^{-1}$, respectively, Tukey's HSD test) but not at KL 9 and $18 \mathrm{~m}$.

Species differences partially explained variation $(<7 \%)$ in the residuals of the regeneration-rate model for the $6 \mathrm{~m}$ sites (period 45 to $154 \mathrm{~d}$ ), with Montastraea annularis having higher regeneration rates than M. franksi $\left(1.3 \pm 0.3 \times 10^{-4} \mathrm{~cm} \mathrm{~d}^{-1}\right.$ vs. $0.8 \pm 0.4 \times 10^{-4} \mathrm{~cm}$ $\mathrm{d}^{-1}$, respectively). However, this was largely a result of an uneven distribution of morphotypes among sites, and the species effect was not significant when added as a covariate to the regeneration-rate model. Species differences did not significantly explain variation in the residuals along the depth gradient. Initial lesion size, perimeter, and shape explained less than $10 \%$ of the residual error in the regeneration (T:P) model at the $6 \mathrm{~m}$ sites $\left([\mathrm{A}] \mathrm{r}^{2}=0.09, \mathrm{p}=0.002 ;[\mathrm{P}] \mathrm{r}^{2}=0.06, \mathrm{p}<\right.$ 0.01 ; $\left.[\mathrm{P}: \mathrm{A}] \mathrm{r}^{2}=0.09, \mathrm{p}=0.002\right)$. Residuals were positively correlated with both initial lesion size and perimeter, and negatively correlated with P:A. Along the depth gradient, lesion size, perimeter and shape were independent of model residuals.

\section{Quasi-annual regeneration rate (319 to 376 d)}

At the $6 \mathrm{~m}$ sites, mean quasi-annual regeneration rates differed among sites (repeated-measures MANOVA: site effect $\left.F_{3,12}=14.8, \mathrm{p}=0.0002\right)$, season $\left(F_{3,36}=11.2, \mathrm{p}\right.$ $<0.0001)$, and with the site $\times$ season interactions $\left(F_{9,36}=\right.$ $4.2, \mathrm{p}<0.0009)$. Corals at AR and WB regenerated significantly faster than corals at KL $6 \mathrm{~m}$ and BNP between June 2001 and 2002 (ANOVA: $F_{3,15}=7.3, \mathrm{p}<0.003 ; 9 \pm 1$ $\times 10^{-4} \mathrm{~cm} \mathrm{~d}^{-1}$ and $9 \pm 0 \times 10^{-4} \mathrm{~cm} \mathrm{~d}^{-1}$ vs. $3 \pm 1 \times 10^{-4} \mathrm{~cm} \mathrm{~d}^{-1}$ and $2 \pm 3 \times 10^{-4} \mathrm{~cm} \mathrm{~d}^{-1}$, respectively, Tukey HSD, Fig. 5A). Corals at BNP regenerated significantly slower than corals at WB between August 2001 and 2002 (ANOVA: $F_{3,14}=3.4, \mathrm{p}<0.05 ;-4 \pm 5 \times 10^{-4} \mathrm{~cm} \mathrm{~d}^{-1}$ vs. $8 \pm$ $1 \times 10^{-4} \mathrm{~cm} \mathrm{~d}^{-1}$, respectively, Tukey HSD) and corals at AR between October 2001 and 2002 (ANOVA: $F_{3,14}=4.8$, $\mathrm{p}<0.01 ; 0 \pm 3 \times 10^{-4} \mathrm{~cm} \mathrm{~d}^{-1}$ vs. $8 \pm 1 \times 10^{-4} \mathrm{~cm} \mathrm{~d}^{-1}$, respectively, Tukey HSD). Corals at AR also regenerated signif- 
icantly faster than colonies at KL $6 \mathrm{~m}$ and BNP between March 2002 and February 2003 (ANOVA: $F_{3,15}=5.3$, p $<0.01$; Fig. $5 \mathrm{~A}_{;} 21 \pm 5 \times 10^{-4} \mathrm{~cm} \mathrm{~d}^{-1}$ vs. $7 \pm 1 \times 10^{-4} \mathrm{~cm}$ $\mathrm{d}^{-1}$ and $2 \pm 5 \times 10^{-4} \mathrm{~cm} \mathrm{~d}^{-1}$, respectively; Tukey HSD). Short-term regeneration rates were significantly correlated with quasi-annual trends $\left(\mathrm{r}^{2}=0.37, \mathrm{p}=0.0001\right.$; regression equation: $\Delta \mathrm{T}: \mathrm{P}$ [annual] $=0.29 \Delta \mathrm{T}: \mathrm{P}$ [short $]+2.3$ )

Mean regeneration rates varied significantly along the depth gradient (repeated-measures MANOVA: site effect $\left.F_{3,10}=4.1, \mathrm{p}=0.04\right)$, with season $\left(F_{3,8}=38.3\right.$, $\mathrm{p}<0.0001)$, and the season $\times$ site interactions $\left(F_{9,19.6}=\right.$ 5.6, p < 0.0007; Fig. 5B). Regeneration rates at KL 3 m exceeded those at all other sites between March 2002 and February 2003 (ANOVA: $F_{3,15}=5.3, \mathrm{p}<0.02 ; 18 \pm$ $4 \times 10^{-4} \mathrm{~cm} \mathrm{~d}^{-1}$ vs. $7 \pm 1 \times 10^{-4} \mathrm{~cm} \mathrm{~d}^{-1}, 6 \pm 2 \times 10^{-4} \mathrm{~cm}$ $\mathrm{d}^{-1}$ and $4 \pm 2 \times 10^{-4} \mathrm{~cm} \mathrm{~d}^{-1}$, respectively; Tukey HSD). Along the depth gradient, short-term regeneration rates explained little variation in quasi-annual trends $\left(\mathrm{r}^{2}=0.10, \mathrm{p}=0.007\right.$; regression equation: $\Delta \mathrm{T}: \mathrm{P}$ [annual] $=0.12 \Delta \mathrm{T}: \mathrm{P}$ [short] + 3.3) due to high variability, especially among colonies at the KL 9 and $18 \mathrm{~m}$ sites.

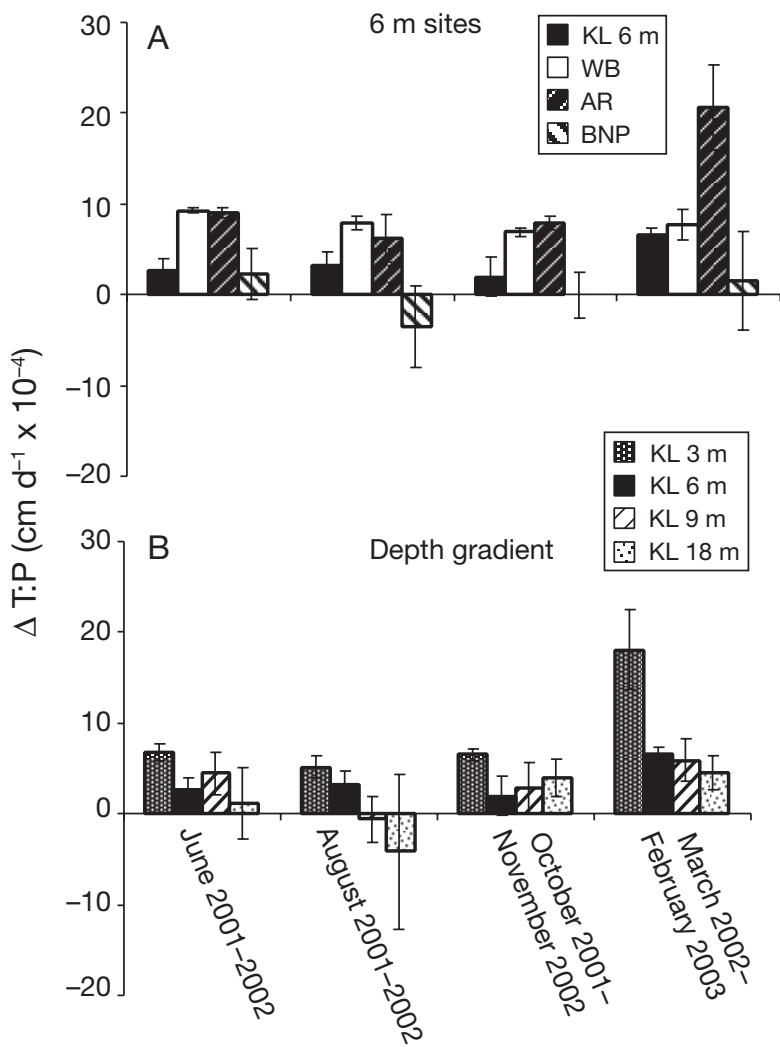

Fig. 5. Montastraea spp. Mean $( \pm \mathrm{SE})$ regeneration rates $(\Delta \mathrm{T}: \mathrm{P})$ standardized to initial lesion perimeter for each season between June 2001 and March 2002, from time of sampling until following year (A) among $6 \mathrm{~m}$ sites, and (B) along 3 to 18 $m$ depth gradient. Rates calculated between June 2001 and 2002 (357 \pm 10 d), August 2001 and 2002 (355 \pm 1 d), October 2001 and November $2002(374 \pm 2$ d) and March 2002 and February $2003(321 \pm 2$ d)

\section{Healed and Type II lesions}

Coral colonies at AR completely healed significantly more lesions (30\%) than colonies at the other $6 \mathrm{~m}$ sites $\left(G_{\mathrm{adj}}=15.8, \mathrm{df}=3, \mathrm{p}<0.005\right)$. Along the depth gradient, significantly more lesions healed completely at $3 \mathrm{~m}$ depth $(31 \%)$ than at other depths $\left(G_{\mathrm{adj}}=12.8, \mathrm{df}=\right.$ $3, \mathrm{p}<0.01$; Fig. 6). These results indicate significant heterogeneity among sites in healing.

Of a total of 171 lesions created at the KL $3 \mathrm{~m}$ and all $6 \mathrm{~m}$ sites combined, only 2 merged with other lesions to become Type II lesions (Table 3). In contrast, at the

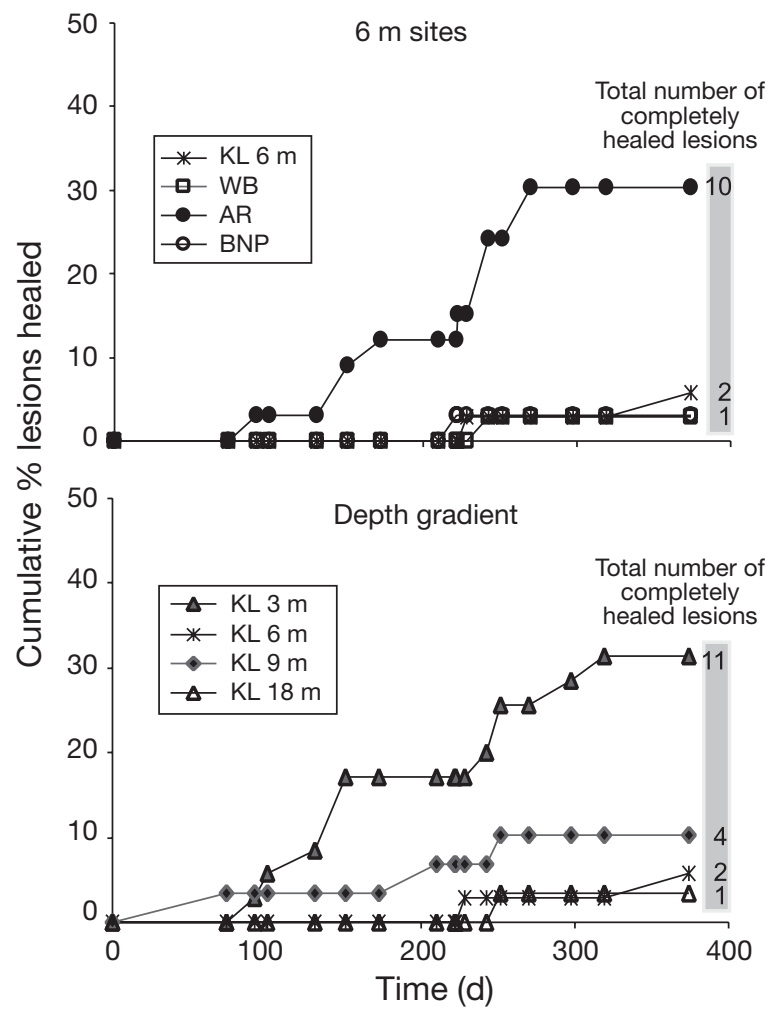

Fig. 6. Montastraea spp. Cumulative percentage (\%) of lesions completely healed over time (A) at $6 \mathrm{~m}$ sites, and (B) along depth gradient. In the shaded region number adjacent to each line is total number of completely healed lesions at the relevant site

Table 3. Montastraea spp. Percentage of healed and Type II lesions (no longer enclosed by living tissue) at each site. Total number of lesions was $<35$ at KL 9 and $18 \mathrm{~m}, \mathrm{AR}$, and BNP due to breakage during sampling (see 'Materials and methods')

\begin{tabular}{|c|c|c|c|c|c|}
\hline \multirow{2}{*}{ Site } & \multirow{2}{*}{ Total no. } & \multicolumn{2}{|c|}{ - Healed - } & \multicolumn{2}{|c|}{ — Type II — } \\
\hline & & No. & $\%$ & No. & $\%$ \\
\hline $\mathrm{KL} \quad 3 \mathrm{~m}$ & 35 & 11 & 31 & 0 & 0 \\
\hline $6 \mathrm{~m}$ & 35 & 2 & 6 & 1 & 3 \\
\hline $9 \mathrm{~m}$ & 29 & 4 & 14 & 6 & 21 \\
\hline $18 \mathrm{~m}$ & 29 & 1 & 3 & 9 & 31 \\
\hline WB & 35 & 1 & 3 & 0 & 0 \\
\hline $\mathrm{AR}$ & 33 & 10 & 30 & 0 & 0 \\
\hline BNP & 33 & 1 & 3 & 1 & 3 \\
\hline
\end{tabular}


deepest sites (KL 9 and $18 \mathrm{~m}$ combined), $26 \%$ of lesions merged to become Type II lesions $\left(G_{\mathrm{adj}}=12.2\right.$, df $=3$, p $<0.01$; Table 3). In 2 cases, lesions joined with another sampled lesion before merging with partial mortality on other parts of the colony, becoming Type II lesions. In all other cases, lesions joined with partial mortality naturally formed on the colony and were often associated with increases in algae, thereby forming Type II lesions.

\section{DISCUSSION}

Following recommendations of Williams (1994) and utilizing the extensive work of Bak, Meesters and coworkers (e.g. Meesters et al. 1997b), we evaluated lesion regeneration as an indicator of coral-colony condition at 7 reefs in BNP and FKNMS. Using this bioindicator, we successfully detected significant differences among sites in mean lesion regeneration rates. While most previous studies of regeneration monitored lesions for 60 to $150 \mathrm{~d}$, we followed regeneration for up to $595 \mathrm{~d}$, which allowed us to observe changes in recovery trends that might be missed by a study of shorter duration. Short-term regeneration rates were useful predictors of longer-term regeneration rates among $6 \mathrm{~m}$ sites, but explained little variation along the depth gradient. Monitoring long-term regeneration appears necessary when comparing coral colonies living in different reef types/depths. Longterm regeneration rates were time-dependent whereas short-term regeneration rates were not.

Coral lesions regenerate at a rate determined by the number of polyps surrounding each lesion (Meesters et al. 1997b, Oren et al. 1997, Lirman 2000b) and normally follow an exponential-decay model with an asymptote at full healing (Meesters et al. 1994, 1997a, Lirman 2000b). We found that changes in lesion size were dynamic and site-dependent and often deviated from the expected exponential-decay model. Some lesions that initially increased in size later regenerated, and other lesions that initially began to regenerate later increased in size, especially at sites with high algal growth (e.g. BNP, and KL 9 and $18 \mathrm{~m}$ ). If lesions with a P:A ratio $>2 \mathrm{~cm}^{-1}$ were able to fully regenerate (Meesters et al. 1997a), then most lesions in our study should have healed completely. However, only $13 \%$ ( $\mathrm{n}=229)$ fully regenerated. The largest lesion $\left(2.0 \mathrm{~cm}^{2}\right)$ that fully regenerated did so after $243 \mathrm{~d}$; after $151 \mathrm{~d}$, this lesion had regenerated $78 \%$ of its area to a size of $0.45 \mathrm{~cm}^{2}$. Most lesions that healed completely regenerated most $(>70 \%$ ) of their area within $151 \mathrm{~d}$, but complete healing often required 1 yr or longer. One lesion that completely healed after $270 \mathrm{~d}$ increased $66 \%$ in size in the first $56 \mathrm{~d}$ before beginning to regenerate.
Our study confirms that regeneration can continue for 1 yr or more and that lesions that do not initially regenerate (or even increase in size) can regenerate later if conditions become favorable.

\section{$6 \mathrm{~m}$ sites}

Mean lesion regeneration rates varied significantly among sites at the same depth, suggesting that lesion regeneration may be a useful indicator of variation in environmental conditions. Of the $6 \mathrm{~m}$ sites, corals consistently had the highest regeneration rates at $A R$, which is adjacent to the extensive John Pennekamp Coral Reef State Park. Colonies at AR had significantly more completely healed lesions than the other $6 \mathrm{~m}$ sites. AR also had the highest live coral cover, with relatively large colonies. Lesions at the other site adjacent to the state park (WB) also regenerated exponentially but many failed to heal completely, leaving these corals susceptible to fouling organisms. Partial coral mortality of the community was lowest at this site. In contrast, KL $6 \mathrm{~m}$, located offshore from the most urbanized coastline of Key Largo, had low regeneration rates and overall live coral cover. Corals from the site in Biscayne National Park, offshore from urban Miami, had the lowest regeneration rates; lesions there often increased in size. Large increases in lesion size at BNP were often associated with seasonal increases in algae (e.g. June 2002), which sometimes resulted in lesions merging together. During our study, BNP corals had poor lesion recovery and also exhibited mortality elsewhere on the colonies. Mean partial mortality of the coral community was highest at this site. In 2000, Montastraea colonies at BNP experienced a severe oxidative and protein denaturing stress, probably due to chemical contaminant exposure (Downs et al. 2005). The colonies we sampled were generally large in size, with substantial contiguous areas of living tissue, suggesting that the stressor(s) causing poor lesion recovery and partial mortality were probably recent, within the last 10 to $15 \mathrm{yr}$ or less. Therefore, if stresses can be identified and alleviated at this site, these large coral heads may survive.

Responses of other reef organisms (e.g. white grunts and foraminifers) at these sites are consistent with observations of lesion regeneration. Downs et al. (2006) compared biomarker levels in white grunts Haemulon plumieri at BNP, WB and KL $6 \mathrm{~m}$, finding evidence for a toxic response to a xenobiotic at BNP. Concentrations of pesticides in grunt livers were highest at KL $6 \mathrm{~m}$ and lowest at WB (Downs et al. 2006). Using abundances of reef-dwelling foraminifers, Hallock (2000) proposed that host algal symbionts can 
indicate whether environmental conditions support calcifying organisms dependent upon algal symbioses; Fisher et al. (unpubl. data) found that abundances of such foraminifers were lowest at BNP and KL $6 \mathrm{~m}$ and highest at WB and AR.

\section{Depth gradient}

Mean regeneration rate also varied among depths, but results depended on how long lesions were monitored. When monitored for <1 yr (45 to $154 \mathrm{~d}$ ), shallowwater $(3 \mathrm{~m})$ corals regenerated significantly faster than corals at $6 \mathrm{~m}$ but not those at 9 and $18 \mathrm{~m}$. KL $3 \mathrm{~m}$ also had significantly more healed lesions than other sites along the depth gradient. For lesions sampled in March 2002 and monitored for approximately $1 \mathrm{yr}$, shallow-water corals $(3 \mathrm{~m})$ showed higher regeneration rates than all deeper-water corals (6 to $18 \mathrm{~m}$ ) along the Key Largo transect. Nagelkerken et al. (1999) observed that deeper-water corals typically receive less radiant energy and therefore may have lower carbon reserves than corals in shallow water. However, this does not explain why KL 9 and $18 \mathrm{~m}$ had mean short-term regeneration rates similar to those of the shallowest site. Also, differences in mean regeneration rates were not seen between the KL $6 \mathrm{~m}$ and the deeper sites.

Regeneration rates of corals from KL 9 and $18 \mathrm{~m}$ were highly variable. Lesions that initially decreased in size often later increased in size, and overall live coral cover at these sites was low $(<7 \%)$. These Montastraea colonies were bioeroded by clionid sponges, making them susceptible to breakage and resulting in greater patchiness of live tissue, possibly reducing the coral's ability to recover from damage. Type II lesions developed more frequently in corals from these deeper sites. Many lesions joined with dead regions that were unrelated to our sampling. In 2 cases, the entire colony died; 1 each at KL 9 and $18 \mathrm{~m}$.

Lesion growth was often associated with increased algal turf, particularly thick turfs mixed with fine sediments. Hall (2001) reported that regeneration was negatively correlated with algal settlement and cover (particularly macroalgae), which requires large energy expenditure by corals to overgrow. In our study, algal turfs and macroalgae fluctuated in abundance, possibly associated with seasonal changes (as in Lirman \& Biber 2000). Some lesions at our sites regenerated when algal biomass declined, but later increased in size as algae grew, shading and possibly killing polyps surrounding the lesions. Particularly in spring and summer, we observed dark reddish cyanobacterial blooms that formed thick mats on the bottom and overgrew portions of these corals.

\section{Comparisions among all study sites}

All sites we sampled had relatively low coral cover $(<20 \%)$ and appeared to be experiencing stress (Fisher et al. unpubl. data). Connell (1997) observed that chronically stressed reefs were less likely to recover from acute or physical disturbances than reefs that were not chronically stressed. We observed that coral colonies along developed portions of the coastline (i.e. BNP, and KL 6, 9 and $18 \mathrm{~m}$ ) were the least capable of recovering from further damage and mortality. Colonies at sites offshore from John Pennekamp State Park (AR and $\mathrm{WB}$ ) recovered from damage despite exposure to potential stressors (e.g. photic stress, contaminants). Although KL $3 \mathrm{~m}$ is along the same portion of coastline as KL 6, 9, and $18 \mathrm{~m}$, lesion recovery and coral condition (36 $\pm 13 \%$ live coral cover) at this site was good. Other studies also have found that Florida's inshore patch reefs appear to be in better condition and have higher coral cover relative to offshore reefs (Beaver et al. 2005). Corals at KL 9 and $18 \mathrm{~m}$ bleached in 1999, while those at KL 3 and $6 \mathrm{~m}$ did not (Fauth et al. 2003).

\section{Effect of colony and lesion characteristics}

Colony size and previous partial tissue mortality (\%) did not significantly affect regeneration rates, probably because colony size was not small enough to limit resources allocated to regeneration (Oren et al. 2001). Once regeneration rate was standardized to perimeter, which is a measure of coral tissue available for regrowth in the surrounding margin (Meesters et al. 1994), lesion area explained only a small percentage of the variation in regeneration rate. Colony morphotype did not have a significant effect on regeneration rate, but since the 3 types were not evenly sampled among sites this could have confounded the results. However, low variation among colonies within sites containing different species suggests that morphotype was not a major factor affecting regeneration. Taxonomic differences between these morphologies remain uncertain (Lopez et al. 1999, Fukami \& Knowlton 2005).

\section{CONCLUSIONS}

To standardize comparisons of lesion regeneration rates, we recommend (1) monitoring lesions of a similar size and perimeter, (2) comparing sites similar in depth and habitat type (i.e. patch reef, fore reef), and (3) monitoring lesions for more than $1 \mathrm{yr}$ because many lesions may require $>200 \mathrm{~d}$ to heal. We also recommend recording the percentage of healed lesions and the occurrence of Type II lesions. 
Based on observations of lesion regeneration rates, we conclude that coral colonies under relatively favorable environmental conditions (e.g. AR, WB, and $\mathrm{KL} 3 \mathrm{~m}$ ) will consistently have high regeneration rates, with lesion sizes decreasing exponentially over time, a high percentage of healed lesions, and a low occurrence of Type II lesions. Likewise, we conclude that less favorable conditions (e.g. KL 6, KL 9 and 18 m, and BNP) can be identified by lesions that exhibit little regeneration, or high variability including increases in lesion size (overall low regeneration rates), low percentage of healed lesions, a high occurrence of Type II lesions, and a high percentage of breakage (indicative of bioerosion). Causes for differences in coral condition at small spatial scales deserve further investigation.

Regeneration rates of coral lesions reflect the ability of colonies to repair damage and therefore can be useful, inexpensive indicators of reef coral condition or of environmental conditions. A caveat of this indicator is that it is not capable of separating effects of coral health versus external environmental factors on lesion regeneration rate. More expensive assays can then be applied to distinguish between stressor types at sites where coral regeneration is compromised.

Acknowledgements. We thank the Florida Fish and Wildlife Research Institute for use of their underwater camera equipment, and R. Curry, C. Downs, J. C. and J. F. Halas, G. Klungness, S. Ryan, S. Viehman and the NOAA Florida Keys National Marine Sanctuary and Biscayne National Park for assistance in the field and with boats. We thank NOAA's National Undersea Research Center (UNCW) and Everglades National Park for housing. This research was conducted under permit numbers BISC-2001-SCI-0022, BISC-2002-SCI0012 and BISC-2003-SCI-0019 from the National Park Service and FKNMS-2001-008 from the Florida Keys National Marine Sanctuary. This work was funded, in part, by National Sea Grant, Environmental Marine Biotechnology Award No. NA86RG0052, Am.7.1 (C.M.W.), by NOAA-NURC-UNCW subcontract 2004-19B (P.H.), and by NSF Grant DEB9727039 (J.E.F.).

\section{LITERATURE CITED}

Bak RPM, Meesters EH (1999) Population structure as a response of coral communities to global change. Am Zool 39:56-65

Bak RPM, Brouns JJWM, Heys FML (1977) Regeneration and aspects of spatial competition in the scleractinian corals Agaricia agaricites and Montastraea annularis. Proc 3rd Int Coral Reef Symp p 143-148

Beaver CR, Jaap WC, Porter JW, Wheaton J and 6 others (2005) Coral reef evaluation and monitoring program, 2004 executive summary, Florida Fish and Wildlife Conservation Commission and University of Georgia, St. Petersburg

Connell JH (1997) Disturbance and recovery of coral assemblages. Coral Reefs 16:S101-S113

Croquer A, Villamizar E, Noriega N (2002) Environmental factors affecting tissue regeneration of the reef-building coral Montastraea annularis (Faviidae) at Los Roques National Park, Venezuela. Rev Biol Trop 50:1055-1065

Downs CA, Mueller E, Phillips S, Fauth JE, Woodley CM (2000) A molecular biomarker system for assessing the health of coral (Montastraea faveolata) during heat stress. Mar Biotechnol 2:533-544

Downs CA, Fauth JE, Robinson C, Curry R, Lanzendorf B, Halas JC, Halas JF, Woodley CM (2005) Cellular diagnostics and coral health: declining coral health in the Florida Keys. Mar Pollut Bull 51:558-569

Downs CA, Fauth JE, Wetzel D, Hallock P, Halas JF, Halas JC, Curry R, Woodley CM (2006) Investigating coral reef degradation at Alina's Reef in the Florida Keys: cellular physiology of white grunt (Haemulon plumieri) as a biological indicator. Environ Forensics 7:15-32

Fauth JE, Downs CA, Halas JC, Dustan P, Woodley CM (2003) Mid-range prediction of coral bleaching: a molecular diagnostic system approach. In: Valette-Silver N, Scavia D (eds) Ecological forecasting: new tools for coastal and ecosystem management, Vol 1. NOAA Tech Memo NMFS NOC NCCOS: $5-12$

Fine M, Oren U, Loya Y (2002) Bleaching effect on regeneration and resource translocation in the coral Oculina patagonica. Mar Ecol Prog Ser 234:119-125

Fukami H, Knowlton N (2005) Analysis of complete mitochondrial DNA sequences of three members of the Montastraea annularis coral species complex (Cnidaria, Anthozoa, Scleractinia). Coral Reefs 24:410-417

Ginsburg RN, Gischler E, Kiene WE (2001) Partial mortality of massive reef-building corals: an index of patch reef condition, Florida reef tract. Bull Mar Sci 69:1149-1173

Hall VR (2001) The response of Acropora hyacinthus and Montipora tuberculosa to three different types of colony damage: scraping injury, tissue mortality and breakage. J Exp Mar Biol Ecol 264:209-223

Hallock P (2000) Larger foraminifera as indicators of coralreef vitality. In: Martin RE (ed) Environmental micropaleontology, Vol 15. Kluwer Academic/Plenum Publishers, New York, p 121-150

Kawaguti S (1937) On the physiology of reef corals. III. Regeneration and phototropism in reef corals. Palao Trop Biol Stn Stud 1:209-216

Kramarsky-Winter E, Loya Y (2000) Tissue regeneration in the coral Fungia granulosa: the effect of extrinsic and intrinsic factors. Mar Biol 137:867-873

Lang JC (ed) (2003) Status of coral reefs in the Western Atlantic: results of initial surveys, Atlantic and Gulf Rapid Reef Assessment (AGRRA) program. Atoll Res Bull 496

Lester RT, Bak RPM (1985) Effects of environment on regeneration rate of tissue lesions in the reef coral Montastrea annularis (Scleractinia). Mar Ecol Prog Ser 24:183-185

Lirman D (2000a) Fragmentation in the branching coral Acropora palmata (Lamarck): growth, survivorship, and reproduction of colonies and fragments. J Exp Mar Biol Ecol 251:41-57

Lirman D (2000b) Lesion regeneration in the branching coral Acropora palmata: effects of colonization, colony size, lesion size and lesion shape. Mar Ecol Prog Ser 197: 209-215

Lirman D, Biber P (2000) Seasonal dynamics of macroalgal communities of the Northern Florida reef tract. Bot Mar 45:303-314

Lopez JV, Kersanach R, Rehner SA, Knowlton N (1999) Molecular determination of species boundaries in corals: genetic analysis of the Montastraea annularis complex using amplified fragment length polymorphisms and a microsatellite marker. Biol Bull (Woods Hole) 196:80-93 
Mascarelli PE, Bunkley-Williams L (1999) An experimental field evaluation of healing in damaged, unbleached and artificially bleached star coral, Montastrea annularis. Bull Mar Sci 65:577-586

Meesters EH, Bak RPM (1993) Effects of coral bleaching on tissue regeneration potential and colony survival. Mar Ecol Prog Ser 96:189-198

Meesters EH, Bos A, Gast GJ (1993) Effects of sedimentation and lesion position on coral regeneration. Proc 7th Int Coral Reef Symp 671-678

Meesters EH, Noordeloos M, Bak RPM (1994) Damage and regeneration: links to growth in the reef-building coral Montastrea annularis. Mar Ecol Prog Ser 112:119-128

Meesters EH, Weeseling I, Bak RPM (1997a) Coral colony tissue damage in six species of reef-building corals: partial mortality in relation with depth and surface area. J Sea Res 37:131-144

Meesters EM, Pauchli W, Bak RPM (1997b) Predicting regeneration of physical damage on a reef-building coral by regeneration capacity and lesion shape. Mar Ecol Prog Ser 146:91-99

Nagelkerken I, Bak RPM (1998) Differential regeneration of artificial lesions among sympatric morphs of the Carib-

Editorial responsibility: Howard Browman (Associate Editorin-Chief), Storebø, Norway bean corals Porites astreoides and Stephanocoenia michelinii. Mar Ecol Prog Ser 163:279-283

Nagelkerken I, Meesters EH, Bak RPM (1999) Depth-related variation in regeneration of artificial lesions in the Caribbean corals Porites astreoides and Stephanocoenia michelinii. J Exp Mar Biol Ecol 234:29-39

Oren U, Benayahu Y, Loya Y (1997) Effect of lesion size and shape on regeneration of the Red Sea coral Favia favus. Mar Ecol Prog Ser 146:101-107

Oren U, Benayahu Y, Lubinevsky H, Loya Y (2001) Colony integration during regeneration in the stony coral Favia favus. Ecology 82:802-813

Sokal RR, Rohlf FJ (1995) Biometry. The principles and practice of statistics in biological research, 3rd edn. WH Freeman \& Company, New York

Van Veghel MLJ, Bak RPM (1994) Reproductive characteristics of the polymorphic Caribbean reef building coral Montastrea annularis. III. Reproduction in damaged and regenerating colonies. Mar Ecol Prog Ser 109: 229-233

Williams I (1994) An investigation into the use of coral lesions as indicators of environmental pollution. MS thesis, University of Newcastle, Newcastle upon Tyne

Submitted: January 27, 2006; Accepted: July 23, 2006 Proofs received from author(s): May 18, 2007 